Pobrane z czasopisma Annales H - Oeconomia http://oeconomia.annales.umcs.pl Data: 26/04/2023 12:51:34

DOI:10.17951/h.2017.51.4.173

\begin{tabular}{lcl}
\hline \multicolumn{3}{c}{ A N N A L E S } \\
UNIVERSITATIS MARIAE CURIE-SKŁODOWSKA \\
LUBLIN - POLONIA \\
VOL. LI, 4 \\
SECTIO H
\end{tabular}

Maria Curie-Skłodowska University in Lublin. Faculty of Economics

PIOTR KOZARZEWSKI

pkozarzewski@poczta.umcs.lublin.pl

\title{
Fiscalization of Ownership Policy of the Polish State During the Post-Communist Transition
}

Fiskalizacja polityki własnościowej państwa polskiego w toku transformacji postkomunistycznej

Keywords: ownership policy; privatization; fiscalism; post-communist transition; Poland

Słowa kluczowe: polityka własnościowa; prywatyzacja; fiskalizm; transformacja postkomunistyczna; Polska

JEL Code: E62; L32; P26; P31

\section{Introduction}

Ownership policy is one of the basic functions of the state in all market economies. In post-communist transition economies, ownership policy of the state meets additional challenges related to the gigantic state-controlled sector inherited from the command economy of the previous system and the necessity to organize deep change in the ownership structure towards predominance of independent private business entities. What is more, ownership transition is not a standalone process and it has to be synergetic with other systemic reforms enhancing the capacities of the government to meet the challenges and goals of post-communist transition. In this context, a question of the framework for the ownership policy of the state arises, especially what should be the ultimate role of the state as an owner in the reformed economy. According to H. Mühlenkamp [2015], two main approaches exist. The first one is a "market failure" approach, where the state is supposed to be in charge 
of controlling production of goods when market mechanisms fail - e.g. to regulate the activities of natural monopolies or to supply necessary public goods or socially important private goods. The second one is a "public choice" approach, where a stateowned enterprise (SOE) is an instrument for the pursuit of a wide range of political goals: from beneficent for the whole society to creating private gains.

The goal of the article is to discuss the evolution of ownership policy of the Polish state during the post-communist transition which, in the author's view, manifests a gradual shift from the first approach towards the second one, through growing tendency to treat public property mainly from a fiscal perspective: as a source of finance for other government's policies rather than a tool of producing public goods. This evolution has a long-term character and is to a large extent independent from official rhetoric of subsequent governments and ruling coalitions. The analysis covers the two pillars of the ownership policy of the state in post-communist transition: a function of organizer of transfer of state-owned property into private hands (henceforth called "privatization policy") and a function of managing the property which stays under control of the state (henceforth called "owner's policy").

The importance of this topic lays in the fact that concentration on short-term fiscal goals poses a threat to meeting of a wide range of long-term goals of the economic policy, increasing risks and decreasing its coherence. Such an approach may put in the shade of immediate gains such strategic issues as, to name but a few, creation of the desired ownership structure of the economy, securing development prospects of companies or stability of financial markets, creating at the same time grounds for vested interests and rent seeking behavior.

Despite a vast amount of studies on ownership transformation (in Poland and other post-communist countries), the literature devoted specifically to the problem of ownership policy of the state in transition and its evolution is quite scarce, especially since the early 2000s, when researchers' interest towards transition in Central and Eastern Europe started to decline. Among the literature devoted to Poland, not numerous recent publications concentrate first of all on general issues of the role of the state in Polish economy: M. Szanyi [2016] studies the changing owner's role of state in Hungary and Poland as a contribution to the development of the theory of Central and East European capitalism models; B. Błaszczyk [2016] puts forward the thesis on the reversal of the ownership transformation policy; and P. Kozarzewski and M. Bałtowski [2017] analyze the changing state role paradigm in this country. Two articles are devoted to selected specific issues such as vested interests in privatization [Senderski, 2015] and the real share of the state in the enterprise sector [Bałtowski, Kozarzewski, 2016]. 


\section{Ownership policy in transition}

In the majority of post-communist countries, including Poland, changes in the ownership policy of the state were a cornerstone of the transition reforms. From the very beginning of the transition, in line with the Washington Consensus approach, there was general understanding among authors of market reforms that the economy must be based on domination of private property - so large-scale privatization was needed both in a wide (change of ownership structure of the economy from state-dominated to private-dominated) and narrow sense (passing state-owned entities into private hands) as its main vehicle.

The main goals of privatization were twofold: systemic (change of the economic system through creation of private entities and depolitization of economy through withdrawal of the state from performing ownership functions for the majority of enterprises) [Åslund, 2007, p. 145] and economic (through solving the problem of microeconomic inefficiency of the state-owned enterprise sector and creation a "private property regime" [Frydman, Rapaczynski, 1994]). At the same time, in Poland the exact target of the systemic goal was never explicitly set $-i$.e. what the ultimate ownership structure of the economy should be and what were the exact criteria for keeping some sectors or even specific companies under the state control. Nevertheless, until the recent years, at least officially, the SOE sector was treated in line with the above-mentioned market failure approach which meant that all the state-owned enterprises should be ultimately privatized except those which must stay in the state hands.

This can explain why among the two pillars of the ownership policy, the Polish governments focused primarily on privatization (especially in the narrow sense), while the state's owner policy remained to a large extent neglected. Only at the end of 2016, a law on the principles of the state corporate governance has been passed (Dz.U. z 2016 r., poz. 2259) - within a radical change of paradigm of the role of the state in the economy which took place in the recent years. According to the new approach, the state stays a powerful player on the market for a longer perspective and even is going to expand its role in certain strategic areas, especially as an owner and investor [Kozarzewski, Bałtowski, 2017].

\section{Fiscalization of privatization policy}

During the first years of transition, systemic and microeconomic goals seemed to be of key importance for the Polish government, but, starting from the second half of the 1990s, the privatization policy became increasingly fiscally-oriented. At the end of the 1990s, it was decided that privatization revenues would finance crucial government expenditures, among others, the ambitious social reform program - including the pension reform, which required extensive government's funding. 
Privatization processes started to include more and more enterprises of high market value, which by the end of the 1990s resulted in steep increase of privatization proceeds to the state budget.

At the turn of the new century, privatization skeptics came to power which (alongside with the world economic recession) led to a drastic slowdown in privatization dynamics and falling privatization proceeds (with some exception in 2004). Low privatization incomes jeopardized implementation of policies which were planned to be financed from them, e.g. contributed to the financial failure of the pension system reform. Thus, privatization stopped performing even its fiscal functions.

After more liberal-minded political forces (coalition of the Civic Platform and the Polish People's Party - Polish acronyms PO and PSL) re-gained power in 2007, privatization dynamics temporarily boosted, although the systemic and economic goals were put aside in favor of fiscal effects. Most of privatization cases were so-called reluctant privatization - the term was coined by B. Bortolotti and M. Faccio [2004] and means transfer of ownership rights without appropriate transfer of control rights: the state was selling minority blocks of shares keeping for itself the controlling blocks [Badanie..., 2011] or preserving control over the company using other tools, despite possessing only a minority block or no shares at all [Bałtowski, Kozarzewski, 2016]. It made possible to have privatization proceeds to the state budget without losing control over the companies. However, since 2011 the privatization dynamics started to fall again (see Figure 1). After the coalition lost the October 2015 elections, the new government, which had been formed by the winning coalition led by the Law and Justice party (Polish acronym - PiS), started to implement an openly statist economic policy and officially excluded privatization from its agenda [Kierunki..., 2015].

Looking at the dynamics of privatization since the beginning of the new century, it may seem that the privatization policy mostly followed the ideology of subsequent

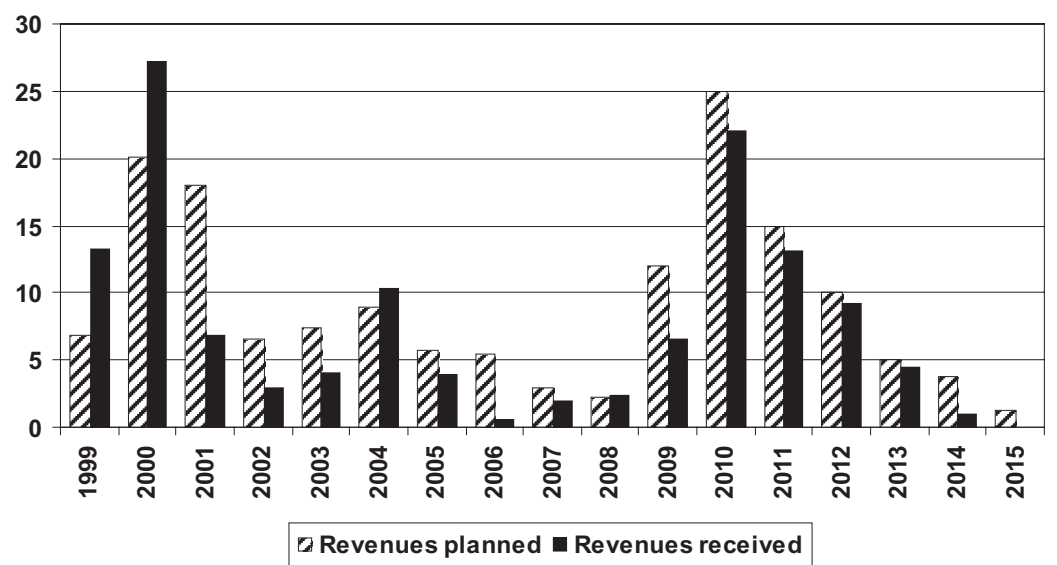

Figure 1. Dynamics of privatization measured by privatization revenues (in PLN bn, current prices) Source: [Ministry of Treasury, 2013]. 
ruling coalitions. Those with more liberal programs, albeit with more reluctant attitude towards privatization, than in the 1990s, for the most part of their rule still considered it as an important tool of their economic policy. While coalitions with statist programs preferred to refrain from selling any of the state property.

However, this explanation is too simplistic and does not cover all the specificity of changes in privatization policy and its possible causes. First, the falling dynamics of privatization in the first half of the 2010s cannot be explained by depletion of state property which could be sold, even within the reluctant privatization approach. The PO-PSL government was closing down its privatization program through removing companies from previously approved privatization lists. As a result, the share of the state sector in the Polish economy is still not only higher than in the majority of the most developed market economies [Development..., 2000; Kowalski et al., 2013], but also, according to the EBRD estimations and Eurostat data ${ }^{1}$, than in the majority of CEE countries.

Second, it can be argued that since about 2003, the pace of privatization has become dependent first of all not on ideology, but on the state budget situation. Fiscal needs of the government stimulated selling of state property; improving fiscal situation, conversely, led to deterioration of the government's will to privatize (see Figure 2). It would explain such "anomalies" as the 2004 one (short re-activation of privatization in the middle of the period of privatization-skeptical governments) and loss of privatization momentum during the last years of the PO-PSL rule. Thus, the fiscal goal not only became virtually the sole reason for privatization, but selling state property became a tool of last resort, when all the other sources of revenues have proved to be insufficient - regardless the ideological stance of subsequent governments.

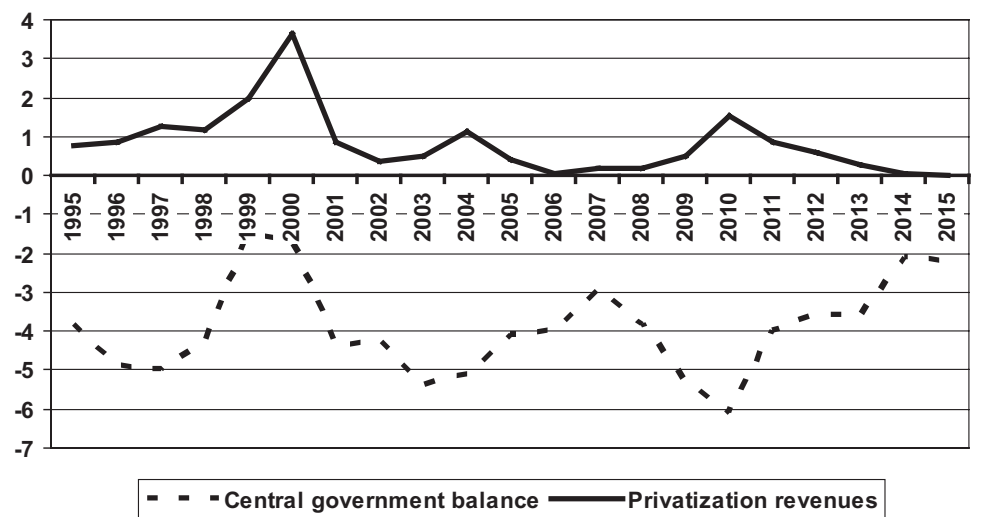

Figure 2. Privatization revenues and the central government balance (in GDP \%)

Source: own calculations based on the data from the Ministry of Treasury and Eurostat.

\footnotetext{
1 www.ebrd.com/what-we-do/economic-research-and-data/data.html; http://appsso.eurostat.ec.europa.eunui/how.do?ataset=gov_10a_ggfa\&lang=en [access: 13.01.2017].
} 


\section{Fiscalization of owner's control}

According to the official discourse, the Polish state performs a role of an owner and manager of enterprises in order to secure vital interests of the society which cannot be achieved through market mechanisms [Ministry of Treasury, 2013]. The existing evidence does not fully corroborate these claims; among others, researches point at rent-seeking groups which use SOEs as a source of their private gains and to a large extent have captured the state's ownership policy [Senderski, 2015; Szanyi, 2016; Kozarzewski, Bałtowski, 2017]. It means that apart from the "market failure" approach, the state in fact unofficially executed elements of the "public choice" approach discussed at the beginning of this article. Since the middle of the 2000s, the latter was enhanced through making the SOE to generate additional proceeds to the state budget - apart from regular taxes paid by the companies.

In 2005, the government started to more actively use the right of the Treasury to receive dividends from its shareholdings. In that year, 5 times more dividends were collected than in 2004; in 2006-2009 and 2013-2015, dividends provided the state with higher revenues than privatization. This solution was equally popular among governments of both more liberal and more statist stance. What is more, the centrist PO-PSL governments (2007-2015) conducted even more active policy of directing SOEs profits to the state budget than the PiS-led coalition (2005-2007) which used much more statist rhetoric - see Figure 3. The new PiS-controlled government declares continuation and even expansion of the policy of using dividend payments for covering its fiscal needs [Jackiewicz ..., 2016].

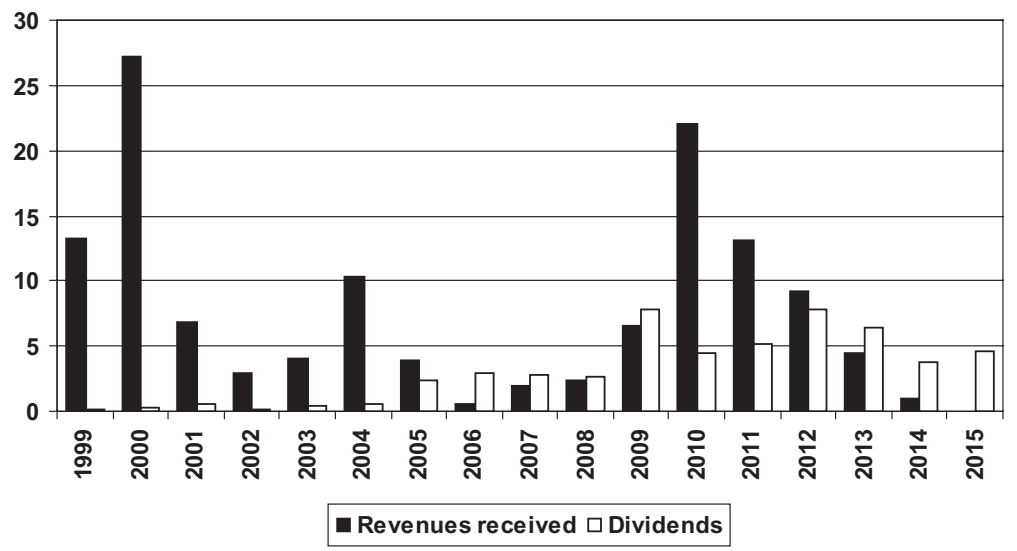

Figure 3. Proceeds to the state budget from privatization and dividends (in PLN bn, current prices)

Source: [Ministry of Treasury, 2013].

Comparing with revenues from state property sales, dividends seem to be a source which is easier to use: plans on dividends were usually over-fulfilled (even as high as 
$272 \%$ in 2008), unlike plans on revenues from privatization, which usually remained unfulfilled. The new record was set in 2015, when privatization revenues amounted to mere PLN 43.6 million (about EUR 10 million), or 3.7\% of the planned amount, while the plan on dividends was fulfilled at $101 \%$ [own calculations based on the Ministry of Treasury data].

Apart from the explicit form of extracting resources from the SOE sector (via the state budget), implicit forms are being evolved. They started to be actively implemented in times of PO-PSL rules; these practices are continued and even expand by the new PiS government. This area of fiscalization of the state ownership policy needs further examination, and detailed description of the methods used is impossible within the limited volume of this article. According to the literature, the most common methods are the following [Sponsoring..., 2012; Senderski, 2015; Kozarzewski, Bałtowski, 2017; Prusek, 2016; Bałtowski, 2016]:

- transfer of resources from profitable SOEs (mainly electric energy producers) to loss-making ones (usually coal mines) through creation of holding structures,

- transfer of resources through very high (several times higher than that of private firms) sponsorship activity of SOEs which supports sports and cultural events,

- engagement of SOEs' capital in the framework of "re-Polonization" of the Polish economy, i.e. replacement of foreign capital with domestic one.

\section{Conclusions}

Fiscalization of ownership policy of the Polish state lies in resignation from privatization as a long-term, strategic tool of economic transition and from state owner's policy as a tool for overcoming imperfections of market mechanisms. Instead, the state-controlled sector is treated mainly as a source of financial resources which can resolve current, mostly short-term needs of the government in overcoming budget deficit and rendering support for selected entities. Such policy, although may lead to temporary improvements in the areas in question, poses serious threat both at macro and micro levels: to the coherence and efficacy of the economic policy of the state and to competitiveness and development prospects of the SOEs which are the subject of extraction of their resources.

At the policy level, subduing privatization, as a strategic instrument, to meeting tactical goals averts attention of decision-makers from creating optimal ownership structure of the economy and private property regime for enterprises - when decisions on whether to privatize and how to do it depend only on whether the state budget is in a desperate need for proceeds or not. Subduing management of state property to the goal of maximization of financial drainage of SOEs hinders de-politization of economic policy: on the one hand, it increases reluctance to privatize and, on the 
other hand, jeopardizes the ability of the state-controlled sector to countervail imperfections of the market and help the government to meet strategic goals of social and economic development.

At the microeconomic level, SOEs suffer from the distorted owner's policy of the state, aimed at maximization of proceeds to the budget instead of maximization of the companies' value (which would be the goal of a private investor). These resources could be invested in development of the companies; additionally, such policy scares minority investors which contributes to falling market valuation of these companies (in the period of May 2015-October 2016, the stock price of the 15 biggest SOEs on the Warsaw Stock Exchange fell 33\% [Czapczyński, 2016]), thus creating even bigger problems with access of SOEs to financial resources, and, as a by-effect, undermining confidence of investors to the whole Polish stock market.

Adverse effects of fiscalization of the state's ownership policy may be mutually reinforcing with growing problems or outright pathologies in the state corporate governance [Kozarzewski, Bałtowski, 2017], especially in the recent period, such as widespread cronyism and politization of personnel policy in the companies and in the governmental agencies which perform ownership functions of the Treasury.

The high degree of continuity of the observed processes of fiscalization may mean that the real roots of them lay much deeper than just a policy choice made by subsequent ruling elites according to their ideological identification. What is more, such continuity is seen in many other aspects of the economic policy. This issue has not been properly studied so far and must become a subject of further research.

\section{Bibliography}

Åslund A., How Capitalism Was Built: The Transformation of Central and Eastern Europe, Russia, and Central Asia, Cambridge University Press, New York 2007.

Badanie i analiza procesów prywatyzacyjnych w ramach wykonywania planu prywatyzacji na lata 20082011. Raport szczegółowy, Ministerstwo Skarbu Państwa, Warszawa 2011.

Bałtowski M., Państwo szkodzi swoim spółkom, „Rzeczpospolita” 2016, 3 listopada.

Bałtowski M., Kozarzewski P., Formal and Real Ownership Structure of the Polish Economy. State-Owned versus State-Controlled Enterprises, "Post-Communist Economies" 2016, Vol. 28, No. 3, DOI: http:// dx.doi.org/10.1080/14631377.2016.1196885.

Błaszczyk B., Odwracanie prywatyzacji w Polsce i na Wegrzech, „Studia Ekonomiczne” 2016 , nr 4.

Bortolotti B., Faccio M., Reluctant Privatization, "Fondazione Eni Enrico Mattei Nota di Lavoro" 2004, No. 130.

Czapczyński P., Klęska państwa na giełdzie, „Rzeczpospolita” 2016, 3 listopada.

Development of Enterprises of Public Participation and of General Economic Interest in Europe since 1996. CEEP Statistical Review, European Centre of Employers and Enterprises Providing Public Services, Brussels 2000.

Frydman R., Rapaczynski A., Privatization in Eastern Europe. Is the State Withering Away?, CEU Press, Budapest 1994.

http://appsso.eurostat.ec.europa.eunui/how.do?ataset=gov_10a_ggfa\&lang=en [access: 13.01.2017].

Jackiewicz: Wygaszamy proces prywatyzacji, „Rzeczpospolita” 2016, 26 lutego. 
Kierunki prywatyzacji majątku Skarbu Państwa w 2016 r. Ministerstwo Skarbu Państwa, Warszawa 2015. Kowalski P., Büge M., Sztajerowska M., Egeland M., State-Owned Enterprises: Trade Effects and Policy Implications, "OECD Trade Policy Paper" 2013, No. 147.

Kozarzewski P., Bałtowski M., Change in the ownership policy paradigm in Poland: state control vs. privatisation, "Acta Oeconomica" 2017, No. 1(67), DOI: http://dx.doi.org/10.1556/032.2017.67.1.1.

Ministry of Treasury, Zasady nadzoru właścicielskiego nad spótkami z udziałem Skarbu Państwa, MSP, Warszawa 2013.

Mühlenkamp H., From State to Market Revisited: A Reassessment of the Empirical Evidence on the Efficiency of Public (and Privately-Owned) Enterprises, "Annals of Public and Cooperative Economics" 2015, Vol. 86, No. 4, DOI: http://dx.doi.org/10.1111/apce.12092.

Prusek T., Ratowanie górnictwa pradem, „Wyborcza.biz” 2016, 17 marca, http://wyborcza.biz/biznes/1,100897,19778099, ratowanie-gornictwa-pradem.html [access: 14.01.2017].

Senderski M., Inhibited Privatization: A Hurdle Race over Vested Interests, "European Journal of Government and Economics" 2015, Vol. 4, No. 1.

Sponsoring - podstawowy instrument marketingu sportowego. Analiza rynku sponsoringu sportowego w Polsce z uwzględnieniem działalności spótek z udziałem Skarbu Państwa, Deloitte, Warszawa 2012.

Szanyi M., The Reversal of the Privatisation Logic in Central European Transition Economies (An Essay), "Acta Oeconomica" 2016, Vol. 66, No. 1, DOI: http://dx.doi.org/10.1556/032.2016.66.1.2.

www.ebrd.com/what-we-do/economic-research-and-data/data.html [access: 13.01.2017].

\section{Fiskalizacja polityki własnościowej państwa polskiego w toku transformacji postkomunistycznej}

Artykuł jest poświęcony ewolucji polityki własnościowej państwa polskiego w toku transformacji postkomunistycznej. Autor stara się udowodnić tezę, że charakteryzuje się ona rosnącą fiskalizacją, czyli traktowaniem własności państwowej, głównie z krótkookresowej perspektywy fiskalnej, jako źródła finansowania bieżącej polityki państwa. Przejawia się to w rezygnacji z prywatyzacji jako strategicznego narzędzia transformacji gospodarczej i z polityki właścicielskiej jako narzędzia do przezwyciężenia niedoskonałości mechanizmów rynkowych. Zaobserwowane trendy stwarzają poważne zagrożenia na szczeblu tak mikro, jak i makro, m.in. dla spójności i skuteczności polityki gospodarczej oraz konkurencyjności i perspektyw rozwojowych spółek kontrolowanych przez Skarb Państwa. Zaobserwowana ewolucja polityki własnościowej ma długoterminowy charakter i tylko w niewielkim stopniu zależy od oficjalnej retoryki kolejnych rządów i koalicji rządzących.

\section{Fiscalization of Ownership Policy of the Polish State During the Post-Communist Transition}

The article is devoted to the evolution of ownership policy of the Polish state in the course of the post-communist transition. The author argues that this policy is characterized by growing fiscalization i.e., treating public property mainly from a short-term fiscal perspective: as a source of finance for the current government's policies. It manifests itself in resignation from privatization as a strategic tool of economic transition and from state owner's policy as a tool for overcoming imperfections of market mechanisms. The observed trends pose serious threat both at macro and micro levels, e.g. to the coherence and efficacy of the economic policy of the state and to competitiveness and development prospects of the state-controlled companies. This policy evolution has a long-term character and is to a large extent independent from official rhetoric of subsequent governments and ruling coalitions. 